\title{
Społeczna konstrukcja praw zwierząt na przykładzie kampanii „Zostań Wege na 30 dni"
}

\author{
Joanna Jaczewska \\ Uniwersytet Gdański
}

DOI: https://doi.org/10.18778/1733-8069.17.2.05

\begin{abstract}
Słowa kluczowe: animal studies, analiza dyskursu, prawa zwierząt, wartości, ruchy społeczne
\end{abstract}

Abstrakt: Klasyczne koncepcje tłumaczące powstawanie wartości i norm społecznych odwołują się do

Joanna Jaczewska, mgr, socjolożka, urbanistka, asystentka w Zakładzie Rozwoju Regionalnego Uniwersytetu Gdańskiego. Interesuje się związkami między dyskursem a procesami społecznymi, a także partycypacją społeczną, percepcją przestrzeni oraz zrównoważonym rozwojem miast. W swoich badaniach wykorzystuje jakościowe i ilościowe metody badań społecznych, analizy przestrzenne GIS oraz algorytmy uczenia maszynowego.

\section{Adres kontaktowy:}

Zakład Rozwoju Regionalnego

Uniwersytet Gdański

ul. Jana Bażyńskiego 4, 80-309 Gdańsk

e-mail: joanna.jaczewska@ug.edu.pl

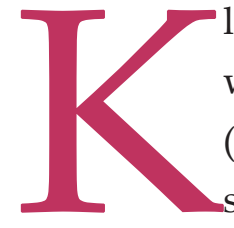

lasyczne koncepcje tłumaczące powstawanie wartości i norm społecznych (Coleman 1990; Habermas 2005; Parrzyści funkcjonalnych zachowań dostosowawczych, umów między członkami wspólnoty lub jej dyskursywnego charakteru - mechanizmów, które w taki czy inny sposób wpływają korzystnie na rozwój większych społeczności ludzkich. Jak jednak można wytłumaczyć pojawianie się norm moralnych w stosunku do przedstawicieli innych gatunków?

W wymiarze teoretycznym zasadniczą ideą artykułu jest rozszerzenie katalogu sposobów powsta- 
wania norm. Według syntetycznego ujęcia Hansa Joasa (2010) pojęcie "genezy norm" występuje w kilku znaczeniach odnoszących się do różnych mechanizmów społecznych. Pierwsze znaczenie to pojawianie się po raz pierwszy w społeczeństwie jakiejś wartości (tworzenie wartości). Po drugie, możemy powstawanie wartości rozumieć jako powiększanie się grupy jej zwolenników, po trzecie, jako zmiany w świadomości jednostek - pojawianie się mocy wiążącej wartości. Po czwarte, może ono polegać na rewitalizacji zapomnianych, niedostosowanych do danych czasów wartości (Joas 2010). Wedle tezy prezentowanej $\mathrm{w}$ niniejszym artykule istnieje jeszcze piąta możliwość. Powstawanie wartości może polegać na ewolucji wartości $\mathrm{w}$ sensie rozszerzania się jej zakresu. Tak rozumiane wartości nie zmieniają się w swojej treści, zmieniają się tylko podmioty, do których je odnosimy, jak dla przykładu rozszerzanie się wartości życia człowieka poza obręb własnego plemienia czy narodu. Można to tłumaczyć zmianą przekonań na temat grup dotąd nieobejmowanych normami wynikającymi z tych wartości ${ }^{1}$. Jak dowodzić będzie niniejszy artykuł, to przesuwanie zakresowej granicy wartości jest jednak złożonym procesem społecznym odbywającym się na poziomie dyskursu definiującego relacje międzygatunkowe.

Prawa zwierząt można rozumieć na kilka sposobów. W języku polskim wyraz „prawo” jest podwójnie dwuznaczny, nie wskazując jasno ani na różnicę między prawem przedmiotowym (ang. law) i podmiotowym (ang. right), ani stanowionym i moralnym. Odnosić się może do regulacji prawnych dotyczących ochrony zwierząt (ochrona przedmiotowa),

${ }^{1}$ Por. ekstensjonizm etyczny - jest to włączanie do wspólnoty moralnej poprzez poszerzanie kręgu moralnego na podstawie podobieństwa $\mathrm{w}$ zakresie cech istotnych moralnie (Francuz 2011; Gzyra 2017). prawa zwierząt sensu stricto - czyli uznawania ich podmiotowości prawnej, jak również do samej idei, że zwierzętom w sensie moralnym należą się określone prawa. Niniejszy artykuł poświęcony będzie głównie temu ostatniemu rozumieniu pojęcia praw, czyli powstawaniu norm moralnych i wartości dotyczących zwierząt. Zarazem mieścić się będzie w ramach paradygmatu animal rights w odróżnieniu od węższego animal welfare protection (Peters 2020). Ten pierwszy pozwala traktować pewne fundamentalne interesy zwierząt jako przyrodzone prawa, wystarczające do nakładania na innych obowiązków i przeważające nad innymi dobrami prawnymi.

Studia nad zwierzętami (animal studies) zyskują w Polsce coraz większą popularność (Barcz, Dąbrowska 2014; Mamzer 2014). Wykorzystanie analizy dyskursu do badań z zakresu relacji człowiek-zwierzę z powodzeniem stosowane jest przez różnych autorów (Rancew-Sikora 2009; 2010; Cukras-Stelągowska 2015). Niniejsze rozważania, wpisujące się $\mathrm{w}$ ten nurt badawczy, skupiają się na problematyce uznawania (Honneth 2012) i urzeczywistniania praw zwierząt w wyniku wpływu działań komunikacyjnych związanych z dyskursem prozwierzęcym. Toteż oprócz badań z zakresu analizy dyskursu przywołane zostały empiryczne badania dotyczące czynników sprzyjających lub blokujących pojawianie się wymienionych procesów. Nawiązuję tu do jednego ze sposobów analizy współczesnych ruchów społecznych, jakim jest kulturowo zorientowany konstruktywizm społeczny, który wraz z teorią nowych ruchów społecznych pojawił się na przełomie lat osiemdziesiątych i dziewięćdziesiątych dwudziestego wieku (Nowosielski 2011). Czołowym przykładem są kulturalistyczne badania Jeffreya Alexandra nad sferą obywatelską (2006), inspirowane późną ideą Durkheima, by badać społeczeństwa nowoczesne w kategoriach klasyfikacji 
symbolicznych (Alexander 1988: 3). W odróżnieniu od fenomenologicznego konstruktywizmu Bergera i Luckmanna (2010), skoncentrowanego na wyjaśnieniu roli socjalizacji $\mathrm{w}$ tworzeniu alternatywnych obrazów rzeczywistości, konstruktywizm kulturalistyczny skupia się na zbiorowych formach mobilizacji społecznej, wykorzystujących odziedziczone zasoby kulturowe.

Przyjmując paradygmat umiarkowanie konstruktywistyczny, a więc zakładając, że konstruktywizm odnosi się jedynie do faktów społecznych (Searle 1999; Kaczmarczyk 2019: 16-18), postanowiono przyjrzeć się strategiom konstruowania praw zwierząt w dyskursie prozwierzęcym. Za pomocą analizy struktury i treści wypowiedzi zrekonstruowano mechanizmy społeczne, które przyczyniają się do adaptacji idei praw zwierząt. Materiał do analizy zaczerpnięty został z kampanii „Zostań Wege na 30 dni”, organizowanej przez Fundację Viva! i przekonującej do tego, by przez miesiąc wypróbować dietę roślinną.

Struktura artykułu odzwierciedla przyjętą procedurę badawczą. Po pierwsze, dokonano przeglądu literatury w zakresie analizy dyskursów ruchów prozwierzęcych, jak również badań empirycznych dotyczących czynników sprzyjających przyjmowaniu wartości. Następnie opisano metody badawcze, źródła danych oraz sposób analizy materiału badawczego. W kolejnej części wyniki zostały przedstawione według czterech głównych wątków badawczych:

a) redefinicji statusu zwierzact, b) redefinicji działań człowieka, c) redefinicji jedzenia zwierząt oraz d) konsekwencji realizacji praw zwierząt.

\section{Ramy, słowa i emocje}

Jednym z podstawowych pojęć używanych $\mathrm{w}$ analizie będą ramy działania zbiorowego, któ- re nawiązują do „ram” (frames) w znaczeniu ukutym przez Ervinga Goffmana, a więc takich kategorii, które „porządkują doświadczenia jednostki i w konsekwencji kierują jej działaniem" (Goffman 1981: 21). Według Williama Gamsona (Gamson 1992 za Nowosielski 2011) ramy tworzone są w wyniku interakcji lub negocjacji, co podkreśla interaktywny i dyskursywny charakter ram. Negocjowanie ram odbywa się nie tylko pomiędzy uczestnikami ruchu, ale również przy udziale osób weń niezaangażowanych i jego przeciwników (Gamson 1992 za Nowosielski 2011). Autorzy reprezentujący podejście ramowe zakładają mnogość ram, które służą do interpretacji różnych fragmentów działalności ruchu społecznego, wyznaczając możliwe działania i formy samoidentyfikacji.

Teoria ramifikacji znaczeń w ruchach społecznych, która w zależności od tłumaczenia terminu „ramifikacja" (framing) występuje również pod postacią „ujmowania w ramy” lub „ramowania” (Burdziej 2011), opiera się na propozycji Davida Snowa i Roberta Benforda (1988). Za Johnem Wilsonem wyróżnili oni trzy bazowe zadania ram wspomagających mobilizację społeczną. Są nimi ramowanie diagnostyczne, prognostyczne i motywacyjne (Snow, Benford 1988). Ramowanie diagnostyczne przedstawia pewne wymiary życia społecznego i zdarzenia w taki sposób, aby odbiorcy zaczęli je postrzegać jako istotny problem, który wymaga wprowadzenia zmian. Ramowanie prognostyczne przedstawia możliwe rozwiązania tego problemu, które szczegółowo pokazują, co należy zrobić, by osiągnać zamierzony cel. Natomiast ramowanie motywacyjne jest realizowane przez apel odwołujący się do powinności lub uzasadnienia, dlaczego warto angażować się w działania ruchu (Snow, Benford 1988). 
Jeszcze inaczej charakteryzują ramy Charlotte Ryan i William Gamson (2006). Piszą oni, że organizują one znaczenia wokół głównej idei, która określa, co jest istotne i wartościowe. Dają pierwszeństwo pewnym sposobom myślenia i mówienia, a inne przesuwają na dalszy plan. Autorzy wyszczególniają cztery podstawowe cechy charakterystyczne ram: 1) fakty nabierają określonego znaczenia i ważności poprzez osadzenie $\mathrm{w}$ ramach, 2) ludzie posiadają niezliczoną liczbę ram interpretacyjnych, każda sytuacja lub zdarzenie mogą zostać przedstawione na kilka sposobów, 3) udane przewartościowanie ramy opiera się na dotarciu do światopoglądu i wartości oponentów oraz 4) wszystkie ramy posiadają pośrednie lub bezpośrednie odniesienia do zasad moralnych (Ryan, Gamson 2006).

Analizy dyskursu organizacji prozwierzęcych w Stanach Zjednoczonych ujawniły podstawowe typy ram, z jakich korzystają aktywiści. Są to: 1) okrucieństwo i cierpienie, 2) utowarowienie, 3) zagrożenie dla ludzi i środowiska oraz 4) zbyteczne zabijanie (Freeman 2010). W odpowiedzi na wskazane problemy aktywiści, którzy winą obarczają przede wszystkim przemysł zwierzęcy, proponują ograniczenie spożywania produktów odzwierzęcych oraz humanitarne reformy. Freeman zaznacza, że w części analizowanych przez nią materiałów aktywiści, stosując ramę poprawienia „dobrostanu zwierząt" (animal welfare), starają się osiągać cele związane z mniej popularną, acz bardziej ambitną ochroną „praw zwierząt” (animal rights) pośrednio i nie wprost. Jeżeli chodzi o odnoszenie się organizacji prozwierzęcych do wartości, podstawą nawoływania do przejścia na weganizm są argumenty z trzech poziomów: 1) altruistycznego, 2) idealistycznego i 3) zdroworozsądkowego (Freeman 2013). Do argumentów altruistycznych autorka zaliczyła: współczucie, szacunek dla czujących istot (dla ich życia i wolności), ochronę środowiska i potrzebę oddolnej zmiany społecznej mającej pomóc ludzkości. Z kolei na poziomie idealistycznym kampanie odwołują się do ideałów takich jak uczciwość (np. nieukrywanie prawdy o realiach przemysłu mięsnego), naturalność (w opozycji do tego, co przetworzone), patriotyzm, sprawiedliwość społeczna (w kontekście korporacyjnego wyzysku). Wreszcie, na poziomie zdroworozsądkowym, odwołują się do takich wartości osobistych jak: własne zdrowie (jest to jeden z najczęściej pojawiających się argumentów zaraz po współczuciu), możliwość wyboru, przynależność i atrakcyjność z perspektywy społecznej (stale zwiększająca się popularność diety roślinnej), wybór smacznego i dostępnego jedzenia oraz duma z osobistej spójności moralnej. Wymienione argumenty są przedstawiane w sposób uwydatniający sprzeczności w postępowaniu. Według Freeman nacisk na spójność moralną stanowi jeden z kluczowych elementów przyciągających do weganizmu, ponieważ zmiany postaw i zachowania zależą prawdopodobnie od powstawania dysonansu poznawczego pomiędzy systemem wartości danej osoby a konsumpcją produktów zwierzęcych (Freeman 2013).

Warto w tym miejscu przywołać współczesne koncepcje związane $\mathrm{z}$ rolą emocji w kształtowaniu się ocen moralnych. Jonathan Haidt (2001) przedstawia w swym artykule społeczno-intuicyjny model wydawania sądów moralnych, który jest propozycją alternatywną wobec tego, co autor nazywa modelem racjonalnym. Haidt definiuje sądy moralne jako „oceny (dobre/złe) działań lub charakteru osoby, wydawane ze względu na zespół cnót uważanych za obowiązujące przez kulturę lub subkulturę" (2001: 817 [tłum. JJ). Autor zaznacza, że jego definicja jest sformułowana bardzo szeroko, bo w zależności od tego, jakie zasady są przyjęte w danej grupie, każda 
sprawa może podlegać ewaluacji moralnej, w tym nawet taka, której na pierwszy rzut oka nie zaliczylibyśmy do materii moralności.

Jednym z głównych założeń modelu jest to, że sądy moralne są rezultatem szybkich i automatycznych intuicji moralnych (the intuitive judgment link), a następnie są uzupełniane o rozumowania moralne (the post hoc reasoning link), które przebiegają wolniej i są przeprowadzane już po wydaniu sądu (Haidt 2001). W odróżnieniu od modelu racjonalnego podkreśla się tu istotny wpływ społeczny i kulturowy na podejmowane decyzje, a zmniejsza wage prywatnego rozumowania jednostki. W myśl tego podejścia rozumowanie moralne jest wytwarzane i przekazywane dalej werbalnie w celu uzasadnienia już wydanych ocen. Te ostatnie zaś rzadko oddziałują na odbiorcę poprzez przekonujące logiczne argumenty, częściej natomiast poprzez wzbudzenie wartościującego afektu w słuchaczu (the reasoned persuasion link).

Potwierdzeniem powyższej propozycji teoretycznej mogłyby być strategie obierane przez organizacje prozwierzęce $\mathrm{w}$ trakcie rekrutacji nowych członków. Istotnym czynnikiem jest ekspozycja na wizualną i werbalną retorykę wykorzystującą symbolikę, która ma na celu wywołanie wstrząsu moralnego (Jasper, Poulsen 1995). Emocje mogą inicjować aktywizm na rzecz praw zwierząt i podtrzymywać trwałość ruchu społecznego (Jacobsson, Lindblom 2013). Praca emocjonalna jest bardzo istotnym elementem $\mathrm{w}$ działaniach aktywistów, pełniąc podwójną rolę. Jest to, po pierwsze, budzenie i podtrzymywanie zaangażowania $\mathrm{w}$ realizowanie ideałów moralnych oraz, po drugie, zmniejszanie stresu często związanego z odchyleniami od powszechnie obowiązujących zachowań - norm (Jacobsson, Lindblom 2013).
Badania sugerują również podobną funkcję emocji w przypadku przechodzenia na weganizm (McDonald 2000). Według Barbary McDonald kluczową rolę może mieć indywidualne „doświadczenie katalityczne” (2000), podobne do omawianego wyżej moralnego wstrząsu i wywoływane przez ekspozycję na przemoc wobec zwierząt. Owa ekspozycja rozpoczyna szereg dalszych reakcji - wyparcie lub działanie. Mechanizm ten jest, według autorki, niezbędny do uruchomienia procesu racjonalizacji i konwersji na styl życia ucieleśniający nowe, niewdrukowane przez socjalizację wartości społeczne (McDonald 2000). Jednak nie u wszystkich proces ten zachodzi natychmiastowo. U części osób jest poprzedzony długim okresem pogłębiania wiedzy i budowania przekonań prowadzących do zmiany stylu życia. Można postawić pytanie, w jakim stopniu drugi model - powolnej przemiany - jest w dalszym ciągu determinowany emocjonalnie (McDonald 2000).

Do repertuaru emocji moralnych, które są szczególnie istotne z perspektywy aktywizmu prozwierzęcego, możemy zaliczyć wstręt. Jego biologiczne pochodzenie jest związane z ochronną reakcją ciała odrzucająca szkodliwe produkty. Paul Rozin, Jonathan Haidt i Clark McCauley (2008) stawiają tezę, że wraz z rozwojem kultur wstręt rozszerzył się również na bardziej symboliczną ochronę duszy przed możliwym „zanieczyszczeniem”, analogicznie do tego, jak ciało odrzuca „złe” jedzenie. Badania sugerują, że odruchowy wstręt (core disgust) jest silniejszy wśród aktywistów prozwierzęcych niż w całej populacji, oraz że wstręt jest związany z przekonaniami na temat zwierząt (Herzog, Golden 2009). Wstręt stanowi przy okazji asumpt do rozważań na temat społecznego zjawiska tabu, które w przypadku diety wegańskiej i wykluczenia produktów odzwierzęcych wydaje się stanowić ciekawą perspektywę analityczną. 


\section{Metody zbierania i analizy danych}

Przyjmując wspomniany już paradygmat umiarkowanego konstruktywizmu, założono, że kluczowym procesem $\mathrm{w}$ toku interakcji jest kreowanie znaczeń oraz interpretowanie i definiowanie sytuacji, co w konsekwencji prowadzi do budowania tożsamości indywidualnych i zbiorowych (Blumer 2007: 63-68; Nowosielski 2011). Zgodnie z myślą Normana Fairclougha, „dyskursy nie tylko odzwierciedlają czy reprezentują podmioty społeczne i relacje, ale również je konstruują i konstytuują" (1992: 3 [tłum. JJ]). Dyskurs może jawić się jako zdarzenie komunikacyjne $\mathrm{w}$ ramach dostarczanych przez szersze konteksty sytuacji społecznych, implikujących, za pośrednictwem interakcji werbalnej, emocje, przekonania i idee (van Dijk 2001). Jednym z zadań analizy dyskursu jest stworzenie zintegrowanego opisu podstawowych wymiarów komunikacji, między innymi językowego, poznawczego oraz interakcyjnego. Chodzi w niej zatem o to, aby odkryć, jak używany język wpływa na wyobrażenia uczestników i dynamikę komunikacji, o wpływ interakcji na język i wyobrażenia oraz to, jak przekonania uczestników warunkują formę językową i przebieg interakcji (van Dijk 2001).

Współcześnie rola mediów, a w szczególności mediów elektronicznych, wraz z upowszechnianiem się dostępu do Internetu, jest szczególnie istotna w kształtowaniu się rzeczywistości społecznej i światów społecznych. Ponieważ ruchy społeczne charakteryzują się stosunkowo niewielką liczbą zaangażowanych uczestników, którzy w dodatku są rozproszeni, Internet staje się istotnym medium rekrutowania i mobilizacji nowych członków oraz kształtowania poczucia wspólnoty (Sztompka 2012).
Aby zrekonstruować mechanizmy społeczne, które przyczyniają się do adaptacji idei praw zwierząt, postanowiono przyjrzeć się dyskursom organizacji prozwierzęcych. Na warsztat wzięto temat konsumpcji produktów odzwierzęcych, który związany jest z codziennymi, osobistymi i społecznymi praktykami ludzi, a zarazem pozostaje w konflikcie $\mathrm{z}$ najbardziej podstawowym (postulowanym) prawem zwierząt do życia. Działania mające na celu przekonanie i zmotywowanie do tak znaczącej zmiany swojego stylu życia jak zaprzestanie - powszechnej w społeczeństwie - konsumpcji zwierząt uznano za istotny temat odrębnej analizy socjologicznej.

Materiał do badań zaczerpnięty został z akcji „Zostań Wege na 30 dni” zorganizowanej przez Fundację „Międzynarodowy Ruch na Rzecz Zwierząt - Viva!", która jest jedną z największych organizacji zajmujących się działaniem na rzecz zwierząt w Polsce. Kampania miała swój początek w październiku 2011 roku, jej uruchomieniu towarzyszyła medialna kampania społeczna (spot wyemitowany przez komercyjne stacje telewizyjne, wyświetlany w Internecie oraz na ekranach umieszczonych w środkach komunikacji miejskiej). Do końca 2020 roku, według danych organizatora, liczba uczestników akcji przekroczyła 170 tysięcy osób². Osoby, które zapisały się do akcji, przez miesiąc otrzymywały pod swoje adresy elektroniczne lub na telefon komórkowy (przez aplikację) biuletyn zawierający podstawowe informacje na temat diety, praktyczne porady, przepisy i jadłospisy wraz z linkami do stron polskich i zagranicznych.

\footnotetext{
${ }^{2}$ Zapisy do akcji i wszelkie informacje o kampanii znajdują się na stronie WWW.zostanwege.pl/zostan-wege-na-30-dni [dostęp 10.01.2021 r.].
} 
Dane uwzględnione $\mathrm{w}$ analizie obejmowały trzydziestodniowy mailing elektroniczny oraz zawarte w nim odnośniki do polecanych artykułów, filmów i stron. Wszystkie materiały poddane analizie zostały utrwalone i zarchiwizowane. $W$ ich skład weszło: 1) trzydzieści odsłon podstawowego biuletynu, 2) siedemnaście dodatkowych artykułów dotyczących tematyki diety, sportu, psychologii oraz zachowań zwierząt, 3) sześć zarejestrowanych na wideo wykładów z zakresu nauk psychologii, filozofii, etologii, medycyny oraz wykładów aktywistów bezpośrednio nawołujących do usunięcia produktów odzwierzęcych z diety, 4) pięć filmów związanych $z$ tematyką praw zwierząt. Materiały wideo zostały poddane transkrypcji. Oprócz elektronicznego biuletynu i odnośników w nim zawartych do materiałów dołączone zostały opinie uczestników na temat programu. Do analizy zostały włączone wszystkie pełne maile opublikowane na stronie WWW, co wzbogaciło materiał o dodatkowe trzydzieści tekstów. Pominięte zostały natomiast wycinki wypowiedzi uczestników pokazywane przez organizatorów akcji w formie krótkich cytatów na stronie WWW, ze względu na brak szerszego kontekstu interpretacyjnego.

Po wstępnym zapoznaniu się z materiałami sprecyzowane zostały główne wątki analityczne. $\mathrm{W}$ toku analizy dokonano selekcji fragmentów, wybierając te, które pokazywały najbardziej wyróżniające się, charakterystyczne motywy o dużym zabarwieniu emocjonalnym lub ocennym. Cytowane fragmenty zostały oznaczone $\mathrm{w}$ porządku, w którym pierwsza, wielka litera oznacza pierwotne źródło materiału - tekst (T) albo wypowiedź ustną (M). Małymi literami opisywany jest typ materiału, czyli: główny korpus biuletynu (biu), dołączony artykuł (art), wywiad (wyw), wykład (wyk), film (mov) lub opinie (opinia), zaś liczba na końcu oznacza, w któ- rym z kolei dniu programu pojawił się ten materiał (od 1 do 30 dnia akcji). Przykładowo, kod „T/biu/20” oznacza, że chodzi o materiał pierwotnie tekstowy, który pojawił się w głównej treści biuletynu w dwudziestym dniu programu.

Struktura biuletynu "Zostań Wege na 30 dni" składa się z krótkich bloków tematycznych wydzielonych nagłówkami. Bloki te składają się z jednego lub kilku akapitów i stanowią wyodrębnione całości treściowe. Informacje opisane są zwięźle, często są wypunktowane, a treść opatrzona jest w pojedynczych miejscach zdjęciami. Często przy nagłówku lub pod koniec bloku znajdują się odnośniki do materiałów powiązanych z omawianym tematem. Zawarte $\mathrm{w}$ badanym biuletynie treści można podzielić na dwie odrębne funkcjonalnie części: instruującą oraz perswazyjną. Ta pierwsza, o charakterze praktycznego poradnika, związana jest z podstawowymi informacjami o diecie, o wartościach odżywczych produktów oraz zawiera przepisy i jadłospisy. Natomiast druga część obejmuje pozostałe materiały włączone do biuletynu, określane przez autorów akcji jako „interesujące” i „inspirujące”. To właśnie ta druga część stanowiła główny przedmiot przedstawionej analizy.

\section{Wyniki badań}

W ramach odpowiedzi na pytanie, w jaki sposób aktywiści przedstawiają argumenty i uzasadnienia dotyczące praw zwierząt, wyodrębnione zostały wymiary, w których dokonuje się kształtowanie wspólnych sensów. Jest to, po pierwsze, redefiniowanie statusu zwierząt oraz wizji natury, po drugie, redefinicja człowieka i jego działań, po trzecie, redefinicja jedzenia zwierząt oraz, po czwarte, ukazywanie konsekwencji uznania i realizacji praw zwierząt (tab. 1). 
Tabela 1. Ramy dotyczące praw zwierząt wyodrębnione na podstawie materiału badawczego

\begin{tabular}{|c|c|}
\hline $\begin{array}{c}\text { Wymiary } \\
\text { problemowe }\end{array}$ & Ramy \\
\hline $\begin{array}{c}\text { status } \\
\text { zwierząt } \\
\text { i wizja natury }\end{array}$ & $\begin{array}{l}\text { - zasypywanie przepaści międzyga- } \\
\text { tunkowej } \\
\text { - granice wspólnoty odczuwania } \\
\text { - natura jako humanistyczna utopia }\end{array}$ \\
\hline $\begin{array}{l}\text { człowiek } \\
\text { i jego } \\
\text { działania }\end{array}$ & $\begin{array}{l}\text { - } \text { szowinizm gatunkowy } \\
\text { - } \text { mordowotna łagodność } \\
\text { - cierpienie jako immanentna anty- } \\
\text { wartość }\end{array}$ \\
\hline $\begin{array}{l}\text { tabuizacja } \\
\text { jedzenia } \\
\text { zwierząt }\end{array}$ & $\begin{array}{l}\text { - skażenie i nieczystość jako tło dla } \\
\text { cierpienia } \\
\text { - kara za niegodziwe praktyki } \\
\text { - produkt spożywczy jako fragment } \\
\text { ciała }\end{array}$ \\
\hline $\begin{array}{l}\text { konsekwencje } \\
\text { realizacji } \\
\text { praw } \\
\text { zwierząt }\end{array}$ & $\begin{array}{l}\text { - } \text { rekonstruowanie spójnej } \\
\text { tożsamości } \\
\text { - dowód społecznej słuszności } \\
\text { - konwersja jako odrodzenie } \\
\text { i oczyszczenie }\end{array}$ \\
\hline
\end{tabular}

Źródło: opracowanie własne.

\section{Status zwierząt i wizja natury}

W analizowanym biuletynie teksty dotyczące zwierząt są istotnym elementem przeplatającym się $\mathrm{z}$ informacjami na temat diety. Oprócz nielicznych opisów warunków, w których przetrzymywane są zwierzęta hodowlane, zdecydowana większość tekstów zamieszczonych w biuletynie dotyczy różnych zwierzęcych zdolności, potrzeb i zachowań, które w powszechnym rozumieniu uważa się za wyróżniające dla gatunku ludzkiego. Do najczęściej wymienianych cech należą możliwości rozumowania i ich korelaty, takie jak inteligencja, samokontrola czy abstrakcyjne myślenie. Poniższe cytaty wyjęte są z tekstów o zwierzętach hodowlanych, w których dany gatunek jest pokazywany z perspektywy jego „naturalnych” umiejętności i zdolności, by w dalszej kolejności konfrontować to z rzeczywistością ferm produkcji przemysłowej mięsa:

Wbrew stereotypom świnie, których dla zbędnych potrzeb konsumenckich zabija się rocznie miliony, potrafią zaskoczyć swoimi zdolnościami poznawczymi. Profesor Donald Broom z wydziału weterynarii Uniwersytetu Cambridge twierdzi, że świnie „mają bardzo rozwinięte zdolności kognitywne. Bardziej niż psy i z pewnością bardziej niż 3-letnie dzieci". Podobnie jak w przypadku psów prosięta uczą się swoich imion w wieku 2-3 tygodni i reagują, gdy się je zawoła. (T/biu/03)

Kury rozumieją związki przyczynowo-skutkowe. Wiedzą również, że rzeczy istnieją, nawet, gdy ich nie ma w zasięgu wzroku. Te zdolności kognitywne kur przewyższają zdolności małych ludzkich dzieci. [...] Dr Christine Nicol, która studiuje inteligencję ptaków, mówi: „Może i są to «ptasie móżdżki», ale musimy zmodyfikować naszą definicję «ptasiego móżdżku». Kury udowadniają nam, że robią rzeczy, o których nie mieliśmy pojęcia". Według Evansa, kury rozumieją, że rzeczy istnieją nawet, gdy są ukryte lub usunięte z zasięgu wzroku. Ten poziom poznawczy jest poza zasięgiem małych ludzkich dzieci. Całkiem niedawno naukowcy udowodnili również, że kury „mogą przewidywać przyszłość i demonstrować samokontrolę - te dwie rzeczy jak dotąd przypisywano wyłącznie ludziom i innym ssakom naczelnym". (T/biu/09) 
Zwykle struktura takich opisów jest podobna. Na początku pojawiają się nawiązania do powszechnych przekonań i zakładanej wstępnej wiedzy czytelników. Następnie wiadomości te są pokazywane jako niezgodne z prawdą. Za przykład służyć mogą określenia takie jak „wbrew stereotypom” czy „wbrew obiegowym opiniom”. Wtedy teksty odwołują się często do odkryć i obserwacji naukowych, podawane są też nazwiska badaczy. Pojawia się również sporo określeń specjalistycznych, takich jak: „związki przyczynowo-skutkowe”, „zdolności kognitywne”, „poziom poznawczy”, a więc pojęcia nadające tekstom rys naukowy, co zapewne ma u czytelników rodzić wrażenie obiektywizmu czy wręcz neutralności światopoglądowej autorów. Wydaje się bardzo znamienne, że opisywane zdolności nie dotyczą swoistych cech gatunkowych czy wyjątkowych możliwości, pod względem których zwierzęta przewyższają naturalne umiejętności ludzi, takich jak na przykład szybkość, siła czy refleks. Punktem odniesienia pozostają raczej dla autorów cechy, za pomocą których człowiek sam tradycyjnie wyodrębnia się ze świata zwierząt. I tak, dla przykładu, pojawiają się między innymi wzmianki o zwierzętach wskazujące, że są one inteligentne, samoświadome, potrafią tworzyć stałe więzi przyjaźni, że potrafią porozumiewać się za pomocą języka czy też, że tworzą zaczątki kultury poprzez przekazywanie z pokolenia na pokolenie pewnych umiejętności, a nawet posiadają formę duchowości (na przykład wzmianka o wyobrażeniach życia po śmierci u gorylicy Koko). Dodatkowo, omawiane umiejętności są często zestawiane z możliwościami ludzi. W obszarze porównań oprócz ludzi można znaleźć również ssaki naczelne oraz zwierzęta towarzyszące (przede wszystkim psy).

Zacieranie granicy odbywa się dwukierunkowo. Oprócz podnoszenia statusu zwierząt, pokazywa- nia ich umiejętności, które dorównują intelektualnym i moralnym możliwościom ludzkim, pokazuje się ewolucyjne powiązania człowieka ze światem zwierząt, podkreślając zwierzęcość człowieka. Bardzo wyraźnie podkreślana jest w omawianych tekstach jego przynależność do grupy naczelnych i ssaków. Pojawiają się na przykład określenia: „ludziom $\mathrm{i}$ innym ssakom naczelnym” albo „wiele naczelnych (w tym ludzi)".

Nie wszystkie teksty charakteryzuje jednak styl naukowy. Wiele opisów dotyczy pojedynczo zarejestrowanych sytuacji, które w swojej stylistyce bardziej upodabniają się do opowieści czy anegdot. Bohaterowie historii często opisywani są z imienia, jak na przykład w wydaniach poświęconych świniom: „Poza wspomnianą wcześniej Pru, która wyciągnęła opiekunkę z bagna, jest też Priscilla, która uratowała młodego chłopca od utonięcia” (T/biu/04). Fragmenty te mają zdecydowanie bardziej emocjonalny charakter i częściej dotyczą historii o niezwykłych czy niecodziennych czynach. Podkreślają potrzeby i motywy kierujące zwierzętami.

Ich głównym wyzwaniem, oczywiście, jest fakt, że hodowane są z przeznaczeniem na ubój - i tak jak wszystkie zwierzęta, nie chcą być oddzielone siłą od swoich rodzin, ani nie chcą umrzeć. Znane są więc historie przebiegłych krów, które zdolne były do dokonania heroicznych czynów, jak np. przeskoczenie dwumetrowego ogrodzenia w celu ucieczki z rzeźni, półgodzinny bieg ruchliwą ulicą, przejście $15 \mathrm{~km}$, aby po sprzedaniu na aukcji wrócić do swojego cielaka, czy przepłynięcie przez rzekę $\mathrm{w}$ celu odzyskania wolności. (T/biu/07)

Analizowany fragment tekstu jest częścią dłuższej notatki o krowach. Pojawia się bezpośrednio pod bardziej rzeczowym komentarzem dotyczącym 
możliwości poznawczych krów. Tekst ten charakteryzuje swobodny styl narracyjny, opisywana historia rozpoczynana jest za pomocą stwierdzenia „znane są [...] historie”, co zmienia rangę podanej informacji. Nie chodzi już o naukowe fakty, a raczej opowieści zbliżone stylem do legend czy mitów. Zwierzęta opisywane są za pomocą słownictwa, którego przeważnie używa się do opisu ludzi. Są to słowa w dużym stopniu nacechowane emocjonalnie i powiązane z ludzkimi wartościami, takie jak „rodzina”, „wolność", „umieranie” i „heroiczne czyny” (zob. Pisarek 2000). W ten sposób tekstom nadawany jest rys patetyczny, pokazywane są poświęcenie i wola życia u zwierząt, jak też ich zdolność do podejmowania ryzyka $\mathrm{w}$ celu realizacji wyższych wartości.

Dążenie do zacierania granicy pomiędzy człowiekiem i światem zwierząt nasuwa pytanie, według jakich kryteriów ustanawiana jest ta granica. Chodzi tu w szczególności o to, jakie gatunki pojawiają się w opisach i jakie argumenty stoją za ich przedefiniowaniem. W tekstach pojawia się tu zdecydowana nadreprezentacja kręgowców, w tym przede wszystkim ssaków. Nie wszystkie zwierzęta są również opisywane na podobnym poziomie szczegółowości. Dla przykładu, ryby jako jedyne są traktowane jako cała gromada bez wyszczególniania pojedynczych gatunków. Wśród opisywanych kręgowców pojawiają się jeszcze ptaki, ale nie ma prawie żadnych wzmianek o gadach czy płazach. Jeśli chodzi o szczegółowy dobór gatunków, można zauważyć, że pierwsza połowa biuletynu dotyczy najczęściej spożywanych zwierząt hodowlanych w Polsce. Natomiast wybór pozostałych zwierząt, które znalazły się w materiałach, sugeruje dużą preferencję dla ssaków, zwłaszcza naczelnych. W badanych tekstach pełnią one $\mathrm{w}$ pewnym sensie rolę ambasadorów świata zwierząt. Wraz z waleniami stanowią również grupę, wobec której pojawiają się najczęściej inicjatywy prawne mające na celu przyznanie im szczególnych quasi-osobowych praw.

Starając się znaleźć gatunkową granicę postulatów przyznawania praw, można znaleźć tylko rozgraniczenie pomiędzy królestwami zwierząt i roślin. Najciekawsza w badanych fragmentach jest właśnie argumentacja tłumacząca wybrany przez autorów podział świata organizmów żyjących:

Nie, rośliny nie czują bólu. Mogą rzecz jasna reagować na różnego rodzaju bodźce, ale nie jest to równoznaczne z subiektywnym odczuciem bólu. Z perspektywy ewolucyjnej ból jest roślinom absolutnie zbędny, jako nic nie znacząca informacja. Zwierzęta mają możliwość obrony lub ataku przed zagrażającym im sytuacjom. Mogą uniknąc źródła bólu. Rośliny nie mają szansy zminimalizowania swojego cierpienia. Nie są w stanie go w jakikolwiek sposób uniknać. Ból nie przyniósłby roślinom jakichkolwiek korzyści ewolucyjnych. Nie ma tym samym powodu, dla którego miałyby go odczuwać. (T/biu/02)

To kolejne fałszywe alibi tych z nas, którzy są przywiązani do mięsa. Nie wykluczam, że rośliny czują, ale na pewno znacznie mniej niż zwierzęta. Wystarczy spojrzeć zwierzęciu w oczy, posłuchać jego głosu, żeby dojrzeć nasze wyraźne z nimi pokrewieństwo w sposobie doświadczania radości i trudów życia. Dlatego przecież potrafimy nawiązywać ze zwierzętami tak silne więzi emocjonalne. $Z$ roślinami tak nie jest. (T/wyw/13)

Warto zauważyć, że świadome odczuwanie i ból są kontrastowo zestawiane $\mathrm{z}$ ograniczoną reakcją na bodźce, która jest wyraźnie oceniana jako mniej znacząca. Właśnie „pokrewieństwo w sposobie doświadczania" wydaje się tu kluczowe. Autor wy- 
powiedzi sugeruje, że człowiek nie jest w stanie wyobrazić sobie sposobu odczuwania roślin, które mają inaczej skonstruowany system odbierania zewnętrznych bodźców. Znacznie łatwiej, według jego opinii, wyobrazić sobie uczucia innej istoty, gdy możemy „spojrzeć jej w oczy” czy „posłuchać jej głosu". W niektórych kręgach, wbrew doniesieniom nauki, do dziś przyjmuje się, że zwierzęta, które nie wydają dźwięków - na przykład ryby - nie odczuwają również bólu. Toteż ludzki sposób odczuwania i charakterystyczne dla ludzkiego gatunku zewnętrzne wskaźniki dyskomfortu i cierpienia wydają się być najbardziej istotne przy wytyczaniu takiej granicy. Skłonność ludzi do empatii i reagowania emocjonalnego $\mathrm{w}$ związku $\mathrm{z}$ obserwowaniem cierpienia drugiego człowieka wydaje się być kluczowa w odniesieniu do podobnych nam ssaków. Jednak im mniejsze podobieństwo i możliwość wczucia się w perspektywę innego organizmu, tym nakreślenie takiej granicy jest łatwiejsze.

Omawiając podłoże uzasadniania praw zwierząt widoczne w analizowanym materiale, warto wspomnieć o jeszcze jednym, bardzo charakterystycznym zjawisku. W tekstach i obrazach dominuje niezwykle idealistyczna wizja przyrody. To człowiek, ingerując w świat zwierząt, wprowadza doń całe zło i nieszczęście. Można odnieść wrażenie, że wśród zwierząt nie ma stosunków drapieżniczych czy pasożytniczych. Fragmenty, w których można znaleźć wzmianki o naturalnym sposobie pozyskiwania pożywienia przez zwierzęta mięsożerne, są pokazywane jako tło dla głównego wątku. Natomiast zasadniczy przekaz częściej dotyczy współpracy, wzajemnej pomocy, przyjaźni czy bohaterskich czynów zwierząt.

Psy zdały sobie sprawę, że nie uda mu się wziąć udziału w kolejnym polowaniu. Zastąpiła go jedyna w stadzie samica, która do tej pory opiekowała sie 16 szczeniętami. Tym samym małe zostały pod opieką Kserkesa. Po powrocie stado nakarmiło rannego psa. Pomimo tego, że Kserkes obiektywnie stał się dla stada ciężarem, pozostałe psy opiekowały się nim aż do zagojenia ran. Co więcej, chroniły go również przed atakami hien. Podobne zachowania zaobserwowano również wśród wielu innych gatunków. Ranne zwierzęta często mogą liczyć na pomoc innych członków stada, nawet w przypadku zagrożenia. (T/biu/24)

Zoolog prof. Sherman podobną sytuację zaobserwował w roku 1978. Zaatakowane zwierzę, które decydowało się w momencie zagrożenia zaalarmować całą grupę, nie miało nigdy szans na ucieczkę. Ratując życie pozostałym, poświęcały własne. Zoolodzy i etolodzy zaobserwowali podobne zachowania również wśród innych gatunków. Zdarzało się wielokrotnie, że obce sobie gatunki pomagały sobie wzajemnie, ostrzegając się przed niebezpieczeństwem. [...] Ten rodzaj poświęcenia ciężko wytłumaczyć nawet teorią altruizmu krewniaczego. (T/biu/25)

Jak można zauważyć w pierwszym cytacie, wątek polowania, który związany jest przecież z zaatakowaniem, uśmierceniem i zjedzeniem innej istoty, jak również karmieniem jej mięsem rannego towarzysza, zredukowany jest do stwierdzenia, że stado wzięło udział w polowaniu i nakarmiło swego członka - bez żadnych obrazowych sformułowań odnoszących się do wiążących się z tym czynności. Podobnie $\mathrm{w}$ drugim tekście, tym razem pisanym z perspektywy ofiary, atak drapieżniczy jest ukryty w sformułowaniach: „zaatakowane zwierzę”, „w momencie zagrożenia” czy „ostrzegając się przed niebezpieczeństwem". Zwierzę, które atakuje, jest odsunięte na dalszy plan, jego rola jest nieistotna. Można stwierdzić, że opisując przyrodę, przytaczane teksty akcentują najbardziej pozy- 
tywne (patrząc z ludzkiej perspektywy moralnej) zachowania wśród zwierząt. Zachowania antagonistyczne, drapieżnicze, o ile w ogóle występują, pokazywane są jako kontekst innych zdarzeń, nie pojawiają się nigdzie jako główny temat. Pokazywany obraz natury zdaje się budować sprzeczny z teorią ewolucji i biologiczną wykładnią rzeczywistości obraz harmonii przyrody bliższy humanistycznej utopii. Pokazuje to dobitnie również fragment tekstu przytaczający historię zaobserwowaną przez bezimiennych badaczy znad jeziora sodowego Ngorongoro:

Etolodzy zaobserwowali ciekawą sytuację w Afryce Wschodniej [...]. Większość [zwierząt - przyp. JJ] przybyła na miejsce samotnie. Jedynie rannej zebrze towarzyszyło całe stado, które cierpliwie czekało na brzegu jeziora, aż kulejące zwierzę nabierze na powrót siły. Niespodziewanie pojawiły się również dwa lwy. Ani zebry, ani gnu nie zareagowały paniką i spokojnie kontynuowały kąpiel. Lwy, skupione na swoich ranach, nie zwracały na nie uwagi. Nad jeziorem Ngorongoro panowała pomiędzy drapieżnikami i roślinożercami pełna harmonia. (T/biu/28)

Poprzez harmonię, która wedle greckiego źródłosłowu oznacza zgodność, ład lub porządek, można rozumieć wzajemne, niezaburzone powiązania między organizmami, na które składa się również sieć zależności pokarmowych i obieg materii w przyrodzie. To właśnie, w jaki sposób użyte jest wymienione słowo w omawianym powyżej cytacie, pokazuje wyobrażenia autorów o porządku panującym w przyrodzie. W przytaczanym fragmencie harmonia oznacza pokój, brak agresji i neutralność pomiędzy istotami żyjącymi jednak w rzeczywistości w antagonistycznych stosunkach. Opisywana historia do złudzenia przypomina raczej ludzkie sojusze i konwencje wojenne ustanawiające strefy pokoju na potrzeby pomocy rannym niż zależności ekosystemowe.

\section{Człowiek i jego działania}

W analizowanym materiale znaleźć można wiele ram, za pomocą których autorzy podejmują próby zredefiniowania status quo, pozycji człowieka i jego działalności. Pierwszym z newralgicznych elementów takich ram jest zespół środków mających na celu zmianę postrzegania stosunku człowieka do innych zwierząt. Podkreślane jest niesprawiedliwe traktowanie oraz brak uzasadnienia istniejącego podziału między gatunkami.

Wielu z nas żyje w towarzystwie zwierząt - psów, kotów czy królików. Dzielą z nami domy i są traktowane jak członkowie rodzin. Opłakujemy ich odejście, kiedy umierają. $Z$ drugiej strony zabijamy i zjadamy zwierzęta, które, jeśli się nad tym zastanowić, wcale nie różnią się od tych, które kochamy. (M/mov/18)

I tak samo jest z dyskryminacją gatunkową (ang. speciesism). [...] Pozwólcie mi zdefiniować znaczenie tego słowa: to nieetyczne, bezzasadne przekonanie, że ludzki gatunek ma pełne prawo eksploatować, niewolić i mordować inne gatunki. Wszystko to w oparciu o wiarę, że nasz gatunek jest tak bardzo wyjątkowy, o tyle lepszy od innych, że tylko my się liczymy i tylko my mamy znaczenie. Poprawcie mnie, jeśli się mylę, ale właśnie takie rozumowanie, taki sposób myślenia jest podstawą wszystkich form dyskryminacji. $(\mathrm{M} / \mathrm{wyk} / 26)$

W powyższych fragmentach zwierzęta domowe są pokazywane w roli podmiotów. Ludzie żyją w ich towarzystwie, dziela z nimi domy, kochają je i opłakują jak przyjaciół. Te zachowania są następnie zestawiane $\mathrm{z}$ niekonsekwentnym, według autorów, 
podejściem do innych zwierząt, które są wykorzystywane i uprzedmiotowiane. Pojawiają się w postaci kotletów i innych produktów na stole. Drugi cytat pokazuje, jak podważane jest nie tylko faworyzowanie pewnej grupy zwierząt, ale w ogóle pozycji człowieka w stosunku do innych gatunków. Uzasadnienie wyższej pozycji istot ludzkich jawi się jako bezzasadne przekonanie i wiara w wyjątkowość człowieka. Niemoralny charakter takiego podziału podkreślany jest zamianą słów „hodowla” i „ubój” na określenia, które opisują naruszanie podstawowych praw człowieka i wyrażają powszechne potępienie („,niewolić” - w kontekście naruszania prawa do wolności, „mordować” - w odniesieniu do prawa do życia). Ostatnie zdanie analizowanego tekstu pokazuje mechanizm funkcjonowania omawianej ramy. Skoro motywy dyskryminacji gatunkowej są podobne do motywów stojących za innymi formami dyskryminacji odnoszącymi się do ludzi, to wedle przedstawianej argumentacji szowinizm gatunkowy również powinien zostać potępiony.

Nie wszystkie ramy wykorzystują motyw równości pomiędzy człowiekiem a innymi gatunkami. Część opiera się na odwrotnym podejściu, czyli na podkreślaniu różnic. Argumenty charakterystyczne dla obu strategii bywają wykorzystywane czasem nawet przez tych samych autorów (na przykład tak jak we fragmentach $\mathrm{z}: \mathrm{M} / \mathrm{wyk} / 26$ ).

I według mnie takie postępowanie jest niewybaczalne i nie przystoi gatunkowi, który twierdzi, że odróżnia dobro od zła! Zwierzęta nie zrobiły nic, aby zasłużyć na tę podłość i okrucieństwo, z którymi je traktujemy. (M/wyk/26)

Ale jest też inne rozumienie słów „czynić sobie poddaną", które wiąże się z odpowiedzialnością i miłością. Jako ludzie obdarzeni jesteśmy inteligencją i sa- moświadomością. Mamy możliwość uświadamiania sobie własnych wyborów, a także trudnych pytań dotyczących sensu istnienia. Dzięki temu w znacznej mierze losy ziemi, losy przyrody zależą od nas. Mamy władzę. Ale z władzą nieodzownie wiąże się odpowiedzialność. (T/wyw/13)

Powyższy fragment ilustruje podejście zogniskowane na różnicach między człowiekiem a innymi gatunkami. Wykorzystana tu rama odwołuje się do unikalnych kompetencji człowieka, jego samoświadomości, inteligencji i zdolności do refleksji moralnej. W konsekwencji rama ta podkreśla wagę odpowiedzialności, jaka spoczywa na człowieku w stosunku do innych gatunków. Odpowiedzialność wynika bowiem ze zdolności decyzyjnych, które mają wyróżniać człowieka spośród innych zwierząt. Zarazem daje ona podstawę do formułowania przez aktywistów wyraźnych oczekiwań normatywnych w stosunku do człowieka.

Niezależnie od próby redefinicji stosunku człowieka do zwierząt, w omawianych tekstach sama opowieść o naturze ludzkiej jest konstruowana w charakterystyczny sposób. Ludzie pokazywani są generalnie jako istoty z urodzenia wrażliwe, pełne empatii, jednak poprzez pewne mechanizmy związane $\mathrm{z}$ doświadczeniem życiowym i socjalizacją zdolne również do dystansowania się i ignorowania podstawowych odruchów. Pokazują to między innymi poniższe fragmenty:

Wszystko, co chcę osiągnąć, to odtworzyć wspólnotę ludzi i zwierząt. Obudzić emocje, uczucia i logiczne myślenie, które zostały celowo stłumione i pogrzebane przez społeczeństwo. [...] Gdyby ktoś źle potraktował zwierzę na naszych oczach, kiedy byliśmy mali, zaczęlibyśmy krzyczeć i płakać. Bo kiedyś umieliśmy wszyscy odróżniać dobro od zła, jeśli chodziło o trak- 
towanie zwierząt. Dopóki ktoś nie oduczył nas tego. $(\mathrm{M} / \mathrm{wyk} / 26)$

Zabicie zwierzęcia jest, samo w sobie, kłopotliwym aktem. Powiedziano kiedyś, że gdybyśmy mieli sami zabijać nasze mięso, bylibyśmy wszyscy wegetarianami. Z pewnością bardzo niewielu ludzi kiedykolwiek odwiedziło rzeźnię, a i filmy z rzeźni nie są popularne w telewizji. Ludzie mogą mieć nadzieję, że mięso, które kupują, pochodzi ze zwierząt, które zginęły bezboleśnie, lecz tak naprawdę nie chcą znać prawdy. $(\mathrm{M} / \mathrm{mov} / 25 / \mathrm{e})$

Podkreślane są tutaj prymarna dziecięca prostolinijność i wrażliwość, które dopiero z wiekiem są tłumione. Autorzy piszą o odtwarzaniu wspólnoty, budzeniu uczuć, czyli nie tyle o wprowadzaniu do ludzkiej natury czegoś nowego, obcego, co raczej o powrocie do korzeni. Okres dzieciństwa jest pokazywany jako ten, w którym człowiek w największym stopniu zdolny jest do właściwej (obiektywnej) oceny sposobu traktowania zwierząt. W drugim cytacie możemy natomiast znaleźć jeszcze bardziej dobitne potwierdzenie „zakrzywienia perspektywy” w kierunku mentalności mieszkańców współczesnych miast w krajach wysoko rozwiniętych. Historia nie potwierdza wniosku, jakoby potrzeba samodzielnego zabijania zwierząt doprowadzała do masowego przechodzenia na dietę roślinną. Jest wręcz coś szczególnego we współczesnych czasach, kiedy ludzie w miastach odłączeni są od procesu produkcji mięsa, a ich główny kontakt ze zwierzętami odbywa się za pośrednictwem zwierząt towarzyszących. Powoduje to, że kontakt z materiałami unaoczniającymi, w jaki sposób odbywa się uśmiercanie zwierząt, może wywołać u części osób silne emocje. Osoby jedzące mięso są przedstawiane jako ludzie żyjący w iluzji, ignorujący rzeczywistość, samookłamują- cy się, ponieważ, według autorów, w inny sposób nie byliby w stanie sprostać prawdzie.

Następnym kluczowym elementem jest sposób, w jaki przedstawiany jest ubój zwierząt. Skala problemu jest pokazywana przy pomocy wielu różnych środków językowych. Wyrażenia fachowe stosowane przy charakterystyce produkowania mięsa, takie jak „ubój”, zastępowane są określeniami wykorzystywanymi typowo w stosunku do ludzi, takimi jak „zabijanie” czy „mordowanie”. By pokazać nieadekwatność obowiązującej hierarchii wartości, zestawia się najistotniejsze i fundamentalne potrzeby zwierząt ze zbytkiem i „fanaberiami” człowieka.

Według oficjalnych danych FAO (Organizacja Narodów Zjednoczonych do spraw Wyżywienia i Rolnictwa) z lat 2003-2007 co roku, dla celów konsumpcyjnych, zabijanych jest na świecie 56 mld (!) zwierząt. Statystyka ta nie wlicza zwierząt morskich, które liczone są nie w sztukach, a w tonach. Prawdziwa liczba przekracza prawdopodobnie 70 mld! Tyle zwierząt co roku cierpi ból fizyczny, nierzadko również psychiczny, tylko po to, by zaspokoić ludzkie fanaberie kulinarne. Nie musi tak być. Możemy zbojkotować ten system wyzysku i cierpienia, wybierając dietę roślinną. (T/biu/01)

A jeśli według Was jest coś takiego jak „humanitarna rzeźnia", to jestem ciekaw, czy dopuszczacie również możliwość „humanitarnego” gwałtu? „Humanitarnego" molestowania dzieci? „Humanitarnego” niewolnictwa? A może „humanitarnego" holokaustu? I właściwie, jaka jest Wasza definicja holokaustu? Czy jest to rzeź istot ludzkich, czy rzeź niewinnych istot? Bo według mnie niewinnych... Tu dochodzimy do największego holokaustu, jaki kiedykolwiek miał miejsce: w Stanach Zjednoczonych, każdego roku, bez litości, mordujemy 10 miliardów zwierząt 
lądowych i 18 miliardów zwierząt morskich. Nie dla zdrowia, ani by się móc wyżywić i przetrwać, i nie w ramach obrony własnej. Ludzie jedzą mięso, ser, mleko i jaja z 4 powodów: przyzwyczajenia, tradycji, wygody i smaku. (M/wyk/26)

Jednym z podstawowych tematów analizowanego materiału jest ukazywanie skali przemysłu mięsnego poprzez dane liczbowe, często mające podstawę w konkretnych źródłach. W pierwszym fragmencie "suche" statystyki są wzbogacone emocjonalną interpretacją. Liczby podkreślane są wykrzyknikami, co wpływa na silniejszy wydźwięk danych, zmniejsza możliwość pozostania wobec nich obojętnym. Autorzy podkreślają również sposób liczenia zwierząt morskich „w tonach”, a więc w skali implikującej traktowanie zwierząt jako niepoliczalnej masy. Jest to zabieg ukazujący formalne uprzedmiotowienie zwierząt poprzez ignorowanie ich jednostkowości w praktyce współczesnych połowów. Wskazywana jest też ciągłość i nieuchronność tego procesu poprzez informowanie, że omawiane fakty mają miejsce „co roku”, „każdego roku”. Zwraca to uwagę na presję czasową, ale też możliwość zmiany sytuacji.

Z kolei drugi fragment jest skierowany bardziej bezpośrednio do słuchaczy; informacje o liczbie zabijanych zwierząt są $\mathrm{w}$ nim zgrabnie poprzedzone wywodem na temat słowa "humanitarny". Wypowiedź ta ma na celu ośmieszenie możliwości opisywania metod zabijania innych istot jako zabiegów humanitarnych. W tym celu autor tworzy ironiczne oksymorony opisujące powszechnie potępiane czyny - na przykład „«humanitarne» molestowanie dzieci” i „«humanitarne» niewolnictwo”. Bezpośrednie zwrócenie się do widzów i pierwsza osoba liczby mnogiej silniej akcentują bezpośrednią odpowiedzialność, a dodatkowy emocjonalny wyraz nadają tekstowi takie określenia jak „rzeź niewinnych”, „,bez litości”, „mordowanie”. Ciekawe jest też użycie nazwy Holokaust jako pospolitego rzeczownika w wyrażeniu „największy holokaust”, które oznacza klasę zjawisk posiadających pewne cechy wspólne. Uzasadnieniem tłumaczącym zabijanie zwierząt mają być, wedle autora, podrzędne zachcianki ludzi, a jedzenie mięsa pokazywane jest przez niego jako współczesny rytualizm, który nie realizuje obecnie żadnych istotnych potrzeb człowieka, utrwalając tylko niepotrzebne okrucieństwo.

Chociaż zabijanie zwierząt jest pokazywane jako niewłaściwe głównie ze względu na brak istotnego uzasadnienia ku temu, to już zadawanie cierpienia oceniane jest negatywnie, niezależnie od celów. Znaczna część analizowanych tekstów stara się pozbawić zabijanie zwierząt oczywistości, która, często od wieków, społecznie doń przylgnęła. Aby rozbić utrwalone schematy myślowe, autorzy wykazują, że zabijanie jest nierozerwalnie związane $\mathrm{z}$ zadawaniem cierpienia. $\mathrm{W}$ poniżej cytowanym fragmencie scenariusza, w którym większość bohaterów przedstawia pozytywne aspekty diety wegańskiej, pod koniec pojawia się stosunkowo krótki epizod zawierający sceny pokazujące warunki przetrzymywania i uboju zwierząt.

Większość ludzi nie kwestionuje zwyczaju zjadania zwierząt, ponieważ zostali wychowani w przekonaniu, że jest to normalne. Ale powodowane cierpienie nigdy nie powinno być uznawane za coś normalnego. $(\mathrm{M} / \mathrm{mov} / 18)$

Ta wypowiedź pojawia się w filmie na chwilę przed pierwszymi scenami z rzeźni. Podmiotowość zwierząt podkreślana jest poprzez użycie słowa „zwierzę" zamiast słowa „mięso”. Scenarzyści podkreślają przy tym, że jest to tylko zwyczaj, utrwalone przekonanie, a nie normatywny stan rzeczy. Po- 
nadto, przyglądając się szczegółowo tym dwóm zdaniom, należy zauważyć, że w pierwszym z nich autorzy używają sformułowania „zwyczaj zjadania zwierząt", by następnie zmienić to wyrażenie na „powodowanie cierpienia”, co świadczy o tym, że traktują oba sformułowania synonimiczne, pozostawiając również taką sugestię odbiorcom. Wspomniane tu oddziaływanie narracji wzmocnione jest przez obraz. Jadące po taśmie produkcyjnej ciała - w kontraście do reszty filmu, który pozbawiony jest podobnych scen - mogą wywołać w osobach niezaznajomionych $\mathrm{z}$ warunkami uboju zwierząt dyskomfort wzmacniający przekaz etyczny.

\section{Tabuizacja jedzenia zwierząt}

W ramach opisów związanych z warunkami chowu i uboju zwierząt, oprócz pokazywania cierpienia zwierząt, pojawiają się teksty, których funkcją jest nie tylko wzbudzenie wśród odbiorców współczucia, ale również negatywnych emocji, takich jak obrzydzenie, wstręt czy strach. Sposoby wzbudzania takich emocji polegają choćby na opisywaniu mięsa jako pokarmu skażonego, za co odpowiedzialne miałyby być obecne warunki chowu i niskie standardy z nim związane. Opisy zawierają często informacje o brudzie, życiu zwierząt wśród martwych współtowarzyszy, we własnych odchodach, które przyciągają pasożyty i generują choroby.

Niestety, to straszliwe cierpienie zwierząt staje się integralnym składnikiem kawałka mięsa lądującym na naszym talerzu. Mięso zwierząt rzeźnych zawiera w sobie nie tylko ogromną ilość adrenaliny, ale także innych toksycznych substancji związanych z ogromnym stresem, jaki przeżywają one na etapie hodowli, w transporcie i w ubojni, jak to się teraz elegancko mówi. Zawiera też środki chemiczne, którymi karmione są zwierzęta, takie jak powodujące szybszy przyrost masy anaboliki i antybiotyki stosowane profilaktycznie przeciw epidemiom zwierzęcym. (T/wyw/13)

Po zmodyfikowaniu genetycznym i karmieniu antybiotykami, aby wywołać nienaturalnie szybki przyrost ich masy, ich serca i kości często nie wytrzymują takiego napływu wagi. Ataki serca i deformacje kończyn przeszły do ich codzienności. (M/mov/25/m)

Władze USA zezwalają na wprowadzanie w obieg mięsa pochodzącego od zwierząt chorych na raka. (M/mov/25/m)

Ze względu na zanieczyszczenie mórz i oceanów ryby mogą być również źródłem wielu toksyn. Według brytyjskich agencji rządowych większość spożywanej przez ludzi rtęci pochodzi właśnie z ryb. (T/biu/16)

Mięso ma wedle autorów akumulować w sobie różne "toksyczne substancje" związane ze "straszliwym cierpieniem”, „ogromnym stresem”. Realia współczesnej produkcji przemysłowej mają też prowadzić do tego, że zawiera ono środki chemiczne, takie jak „anaboliki” i „antybiotyki”, którymi zwierzęta są karmione niczym jedzeniem. Sporo tekstów akcentuje również inne aspekty składające się na nienaturalność chowu zwierząt. Pojawiają się określenia mówiące, że zwierzęta są genetycznie zmodyfikowane, co w konsekwencji ma prowadzić do ich zdeformowania. Informacje o zanieczyszczeniach pojawiają się również $\mathrm{w}$ odniesieniu do ryb, które uważane są w diecie tradycyjnej za zdrowszą alternatywę wobec czerwonego mięsa, jednak i one mogą być źródłem wielu toksyn.

Szczegółowe opisy warunków, w jakich żyją zwierzęta, i możliwych skażeń mięsa pochodzącego 
z ferm przemysłowych są wzmacniane przekazem dotyczącym konsekwencji opisywanego stanu rzeczy dla osoby jedzącej mięso, a więc bezpośredniego wpływu, jaki może mieć na zdrowie taki, a nie inny sposób traktowania zwierząt. W dużo większym stopniu niż reszta produktów odzwierzęcych, takich jak nabiał czy jajka, mięso prezentowane jest jako główny czynnik chorób:

Mięso dzisiaj jest nowym azbestem - bardziej zabójczym niż tytoń. (M/wyk/09)

Wszyscy jesteśmy z natury weganami. Mięso, ser, mleko i jajka zaczynają nam smakować dopiero po tym, jak w dzieciństwie zmuszono nas do ich jedzenia. [...] Ale jeśli jemy to, co chodzi, co lata i co pływa, to właśnie jest anormalne. Co według Was wywołuje choroby? (M/wyk/26)

W hatha-jodze nie sposób przejść bardziej wymagających assanów, gdy umysł zatruty jest agresją, a ciało zakwaszone mięsem. (T/wyw/13)

Mięso powoduje wiele rodzajów raka i chorób serca. Czy mogliby wymienić jedną chorobę spowodowaną dietą wegetariańską? (M/wyk/09)

Podczas 17-sto letniej obserwacji kalifornijskich wegetarian, naukowcy zauważyli, że w przypadku włączenia do diety wegetariańskiej mięsa raz w tygodniu, długość życia ulegała skróceniu o 3, 6 lat - głównie w wyniku udaru i choroby niedokrwiennej serca. (T/biu/28)

Umieralność w wyniku chorób serca jest o 32\% niższa wśród wegetarian niż ogólnej populacji. W dostępnych badaniach, nawet okazjonalne spożycie mięsa (mniej niż raz w tygodniu) wiązało się z gorszymi wynikami, a korzyści odnosiły osoby będące wegetarianami co najmniej pięć lat. (T/biu/28)
Jedzenie mięsa pokazywane jest jako rodzaj wynaturzenia, coś „anormalnego”, co wpływa szkodliwie na zdrowie - „wywołuje choroby" i „,zakwasza” ciało. Co więcej, nie tylko spożywanie dużych ilości mięsa ma mieć negatywne konsekwencje. Przytaczane rezultaty badań dowodzą, że nawet jego okazjonalne czy sporadyczne spożycie skraca długość życia oraz wiąże się z gorszymi wynikami badań medycznych. Autorzy sugerują więc całkowite usunięcie mięsa z diety, a nie tylko jego ograniczanie. Może sprzyjać to budowaniu tabu związanego z jedzeniem mięsa. Nie dość, że produkcja mięsa wiąże się nierozerwalnie z zabiciem jakiejś czującej istoty - czego nie da się oddzielić od zadawania cierpienia - to dodatkowo mięso jest skażone, toksyczne, pochodzi ze zdeformowanych i chorych istot, więc jego spożycie może przynosić negatywne konsekwencje zdrowotne.

Niezależnie od konsekwencji związanych z osobistym zdrowiem, produkcja mięsa ukazywana jest również jako główny problem środowiskowy, od którego rozwiązania zależy dobro planety i gatunku ludzkiego.

Jeżeli nie przestaniemy schlebiać naszym słabościom i przyzwyczajeniom, naszej chciwości i arogancji, zaszkodzimy światu, za który jesteśmy odpowiedzialni. Zaszkodzimy również sobie, bowiem jesteśmy nieodrodnymi dziećmi tej ziemi i bez niej nie przeżyjemy ani chwili. Tymczasem gigantyczna produkcja mięsa wpływa fatalnie na środowisko. [...] Udowodniono także, że choroby cywilizacyjne związane są m.in. ze zbyt dużą ilością mięsa w naszej diecie. Takie są niektóre tylko konsekwencje czynienia sobie ziemi poddaną w sposób arogancki i nieodpowiedzialny. (T/wyw/13)

Gdy tylko spojrzymy wstecz, jak zwierzęta wpływają na nasze zdolności przeżycia, naszą absolutną zależ- 
ność - towarzystwo, jedzenie, ubrania, sport i rozrywka oraz badania naukowe. Ironicznie widzimy tylko gatunek człowieka, który nie ma kompletnie szacunku do tych nie-ludzkich istot. [...] Teraz stajemy twarzą w twarz z nieuniknionymi konsekwencjami. [...] Nie dziwne więc, że choroba szalonych krów, Pfiesteria i inne choroby dotyczące zwierząt dotknęły również ludzi. To nie natura jest odpowiedzialna za te choroby, TYLKO MY. (M/mov/25/e)

Wskazywany tu wpływ na środowisko jest wręcz pokazywany jako potwierdzenie i kara za niegodziwe praktyki „czynienia sobie ziemi poddaną”. Zacytowane wyrażenie nawiązuje do starotestamentowego opisu stworzenia świata, ale podkreśla również, jak wypaczona ma być przez człowieka interpretacja boskiego zalecenia. Autorzy podkreślają, że głównym powodem takich konsekwencji środowiskowych jest wywyższanie się człowieka ponad świat zwierząt i lekceważenie innych istot. Równocześnie jest jednak podkreślana odpowiedzialność człowieka, jego założony wyższy status, świadomość i zdolność przewidywania skutków swoich działań.

Poza przedstawianiem zagrożeń związanych z jedzeniem mięsa, pojawia się jeszcze jedna strategia ramowania tego zagadnienia. Bardzo duże znaczenie wydaje się w niej mieć zmiana postrzegania mięsa poprzez przesunięcie znaczeniowe $-\mathrm{z}$ produktu do jedzenia staje się ono czymś podobnym do ludzkiego ciała. Samo to przesunięcie semantyczne, powiązanie znaczenia mięsa z żywym zwierzęciem, które posiada podobne organy i wydzieliny jak człowiek, ma wywołać zasadniczą zmianę percepcji i wpływać na reakcje odbiorców.

Miód pochodzi dokładnie z żołądka pszczół, jest zwróconym przez nie pożywieniem, spytajcie o to jakiegokolwiek eksperta od zwierząt. Ale nikt nie chciałby jeść płatków z orzechami i wymiocinami, chcemy płatki z orzechami i z miodem, więc bawimy się w to wymyślanie eufemizmów i sami się okłamujemy. Standardowa dieta osoby jedzącej mięso to: krew, mięśnie, naczynia krwionośne, ścięgna i inne tkanki, krowie wydzieliny, kurza menstruacja i wymiociny pszczół?!?! [...] I ludzie myślą, że to weganie są dziwaczni? Bo jemy tofu? I ryż? Fasolę? Soczewicę? (M/wyk/26)

Cytat ten pochodzi z wykładu, w trakcie którego aktywista dokonuje przeramowania diety opartej na produktach odzwierzęcych. Łączy mięso z nazwami anatomicznymi, określeniami takimi jak „krew, mięśnie, naczynia krwionośne, ścięgna i inne tkanki”. Mleko zamienia się w jego wypowiedzi w „krowią wydzielinę", a miód w „wymiociny". Produkty kojarzące się w codziennym życiu z czymś do zjedzenia mają oto wzbudzać wstręt jako wydzieliny i substancje pochodzące od zwierząt. Najistotniejsze wydaje się $\mathrm{w}$ tym procesie semantycznym przeramowanie anonimowego produktu, jakim jest mięso, na ciało żyjącej istoty.

Wśród opinii wyrażonych w stosunku do omawianego programu znaleźć można było odpowiedzi pochodzące od osób, które radykalnie odrzuciły wszystkie produkty odzwierzęce. Pojawiała się też postawa charakteryzująca się zdecydowanym odrzuceniem mięsa i ewentualnym ograniczeniem innych produktów odzwierzęcych. Ciekawe są fragmenty wypowiedzi wskazujące na wstręt związany właśnie z ciałem zwierząt:

Na początku stycznia przez przypadek trafiła w moje ręce książka „Zjadanie zwierząt” Foera. Dotąd, kiedy ktoś chciał pokazać mi filmik z ferm mięsnych, odmawiałam, myśląc, że to, co pokazują te filmy, to poje- 
dyncze przypadki. Po tej lekturze nie mogłam już patrzeć na regały z mięsem w supermarkecie. (T/opinie)

Co prawda odkładałam ten dzień coraz bardziej, bo trzeba było wyjeść resztki zwierząt z lodówki, ale pewnego dnia, kiedy lodówka była już pusta, a ja byłam zapisana do akcji, poszłam do sklepu i zapełniłam cały koszyk niemięsnymi produktami. (T/opinie)

Ps. Miało być na jakiś czas - ale jednak wolę zostać roślinożercą na stałe, nie umiem już nawet znieść zapachu mięsa w sklepie. (T/opinie)

Wykorzystanie wyrażeń takich jak „resztki zwierząt" zamiast słowa "mięso", jak również opisywana zmiana reakcji na odczuwany zapach czy sam widok mięsa, określanie tych doznań jako niemożliwych do zniesienia ujawniają właśnie opisywaną zmianę percepcji.

\section{Konsekwencje realizacji praw zwierząt}

Dieta pozbawiona mięsa jest przedstawiana jako jedna z najlepszych form działań związanych z ograniczaniem eksploatacji zwierząt. Choć $\mathrm{w}$ biuletynie nie znalazły się informacje nawołujące wprost do weganizmu (czyli, oprócz mięsa, wykluczenie wszystkich pozostałych produktów odzwierzęcych, przy których wykorzystywane są zwierzęta), to pewne sugestie czy nawet bardziej bezpośrednie wskazania pojawiły się w materiałach dodatkowych, ukazujących weganizm jako najbardziej konsekwentne rozwiązanie. $W$ podstawowym korpusie biuletynu weganizm i wegetarianizm nie są wartościowane, ani wzajemnie przeciwstawiane, lecz raczej traktowane wymiennie ${ }^{3}$.

${ }^{3}$ Chociaż na pierwszych stronach biuletynu możemy przeczytać o wspieraniu przez autorów akcji „drogi do wegetarianizmu", to przedstawione tam propozycje jadłospisów są w cało-
Natomiast w materiałach dodatkowych dołączonych do biuletynu nawołania do weganizmu są już znacznie częstsze. Pojawiają się teksty opisujące dietę roślinną z perspektywy akcentującej bardziej identyfikację społeczną i procesy budowania tożsamości:

Kiedy już zobaczysz okrucieństwo związane z hodowlą zwierząt na mięso, zrozumiesz, dlaczego miliony współczujących ludzi zdecydowało się usunąć je ze swoich talerzy, na dobre. (M/wyk/25/m)

Ale weganizm to jest szansa, by rzeczywiście wprowadzić w życie wartości, o których wszyscy zawsze tylko gadają. To jest Wasza szansa, by pokazać innym, że naprawdę zależy Wam na pokoju. To jest szansa na osobistą rewolucję. Na zostawienie swojego śladu na tej planecie, przez niewyrządzanie krzywdy! Zawsze bycie weganinem. $(\mathrm{M} / \mathrm{wyk} / 26)$

Wegańska dieta i wegański styl życia są najlepszą formą protestu przeciwko eksploatacji zwierząt. To podejmowanie codziennych działań w celu zmniejszenia cierpienia i śmierci zwierząt poprzez redukcję popytu na wszelkie produkty odzwierzęce. (M/mov/18)

Weganizm jest prezentowany jako dieta współczujących ludzi, pojawia się w kontekście ograniczania „okrucieństwa”, „niewyrządzania krzywdy” czy krzewienia „pokoju”. Autorzy podkreślają, że wega-

ści roślinne - czyli wegańskie. Przekaz kampanii ogniskuje się na pozytywnym motywowaniu czytelników do jedzenia roślinnego. Bezpośrednie nawoływania do wykluczenia dotyczą mięsa, jednak argumenty dotyczące pozostałych produktów odzwierzęcych też są obecne. "Wege" - słowo, które znajduje się w tytule akcji - oznaczające zarówno wegetarianizm, jak i weganizm, dobrze ilustruje pewną niejednoznaczność przesłania kampanii. Takie podejście do przedstawiania tej kampanii mogło mieć na celu zmniejszenie radykalnego wydźwięku kampanii (brak ortodoksyjności), obniżenie startowej poprzeczki, która ustawiona zbyt ambitnie mogłaby zniechęcać potencjalnych uczestników akcji. 
nizm jest szansą na pozostawienie "swojego śladu” w świecie właśnie w formie niezgody na „eksploatację zwierząt". Autorzy przekonują, że dzięki takiemu stylowi życia możemy pokazać innym, jak bardzo zależy nam na wartościach, które wyznajemy, że daje nam on możliwość wewnętrznej „rewolucji” oraz podjęcie działań mających konkretny wpływ na polepszenie sytuacji zwierząt.

Oprócz kwestii związanych z identyfikacją z grupą pojawiają się $\mathrm{w}$ analizowanych tekstach również argumenty przedstawiające społeczną atrakcyjność omawianej idei. Wykorzystywane są w tych argumentacjach informacje na temat liczby osób będących na diecie bezmięsnej, jak również wskazania, że pewne zmiany są nieuniknione.

Ale na szczęście świat się zmienia. [...] Wiktor Hugo powiedział „nie ma nic potężniejszego od idei, której czas nadszedł". Prawa zwierząt są obecnie najważniejszą kwestią sprawiedliwości społecznej od czasów zniesienia niewolnictwa. Czy wiecie, że na świecie jest ponad 600 milionów wegetarian? To więcej niż Stany Zjednoczone, Anglia, Francja, Niemcy, Hiszpania, Włochy, Kanada, Australia i Nowa Zelandia razem! Gdybyśmy byli jednym narodem, byłoby nas więcej niż wszystkich mieszkańców w 27 krajach Unii Europejskiej! (M/wyk/09)

Wegetarianie i weganie stają się coraz większą grupą konsumentów, z którymi liczyć musi się także przemysł mięsny. Zostając wegetarianami, możemy tylko zyskać. Świadomość, że dzięki naszej diecie nie uczestniczymy w procesie uprzedmiotawiania i eksploatacji zwierząt daje olbrzymią energię i satysfakcję. Wykorzystajmy ją :) (T/biu/30)

Prawa zwierząt są tu stawiane w jednym szeregu z rozwojem praw człowieka jako następny krok w rozwoju sprawiedliwości społecznej. Dokonująca się nieuchronna zmiana inspirowana cytowanym zdaniem Hugo ma być potwierdzona przez aktualną liczbę wegetarian na świecie. Są oni metaforycznie agregowani do jednego „narodu” i zestawiani z liczebnością dużych państw. Z kolei w drugim cytacie liczba osób rezygnujących z mięsa pokazywana jest jako rosnąca siła społeczno-polityczna, która zaczyna stanowić zagrożenie dla dystrybutorów mięsa.

W kontraście do informacji mówiących, jakie konsekwencje powoduje jedzenie mięsa, pojawiają się też doniesienia, w jaki korzystny sposób działa stosowanie diety roślinnej. Oprócz wskazywanych korzyści fizycznych w analizowanych wypowiedziach pojawiały się również informacje na temat ogólnej poprawy jakości życia, samopoczucia i wewnętrznej harmonii. Jedna z wypowiedzi nawiązuje nawet do zmian charakterologicznych spowodowanych usunięciem z diety mięsa. Co ciekawe, poprawa w wymiarze psychicznym jest charakterystycznym motywem wypowiedzi uczestników, nadsyłanych do organizatorów programu:

Od 2 tygodni nie jem mięsa i nawet nie mam ochoty na plasterek szynki czy kotleta. Nie sadziłam, ze mój organizm bez żadnych sprzeciwów przyjmie zmianę diety. Wręcz przeciwnie, czuje się lżej fizycznie, bo dieta pobudziła prace jelit, ale również i psychicznie, bo wiem, że nie przykładam ręki do śmierci zwierząt. (T/opinie)

Obecnie mogę powiedzieć, że już od prawie dwóch miesięcy nie jem mięsa i naprawdę czuję się świetnie. Przede wszystkim żyję teraz w zgodzie ze sobą i swoim światopoglądem, do tego czuję się o wiele lepiej, moje niedobory witamin nagle się wyrównały (ostatnimi miesiącami już desperacko brałam suplementy 
i nie było poprawy), jestem teraz o wiele szczęśliwszym człowiekiem. (T/opinie)

Nie jedząc mięsa, robię sobie dobrze. Nie czuję żadnego braku. [...] Tak mówi większość osób, które zdecydowały się nie jeść mięsa. Poprawia im się jakość życia, czują się zdrowsze, bardziej w zgodzie ze sobą. Mają spokojne sumienie, bo ich stół nie jest już stołem krwawej i niepotrzebnej ofiary. (T/wyw/13)

Gdy 30 lat temu przestałem jeść mięso, poczułem wyraźną zmianę. Stałem się bardziej wrażliwy, cierpliwy, rozumiejący. (T/wyw/13)

Autorzy powyższych stwierdzeń uważają, że zaczęli żyć „w zgodzie ze sobą”, czują się „lżej psychicznie” w związku z tym, że nie przykładają ręki do krzywdzenia czy zabijania zwierząt. Zmiana ta wpływa korzystnie na ich samopoczucie, zadowolenie z siebie, a nawet szczęście. Zmiana diety przyniosła doświadczenie wyraźnej ulgi albo wręcz oczyszczenia i odrodzenia. Można więc założyć, że osoby te, dowiadując się o okolicznościach opisywanych w newsletterze, doświadczyły psychicznego dyskomfortu, który został zredukowany przez zmianę diety.

\section{Wnioski}

W analizowanym materiale dużą rolę odgrywają opisy pełniące rolę zacierania granicy między człowiekiem a zwierzęciem. Można je tłumaczyć systematycznym wykorzystaniem ram relatywizujących wyjątkowość człowieka i podważających jego rzekomo nadrzędną pozycję w tych wszystkich sferach, w których przyznaje sobie pierwszeństwo nad innymi gatunkami. Materiały nawiązujące do źródeł naukowych pokazują niezwykłe podobieństwa między człowiekiem a zwierzęciem w możliwościach poznawczych czy posiadaniu samoświadomości. W innych przypadkach „natura" okazuje się być szczególną projekcją - prezentowana jest jako humanistyczna utopia, w obrębie której podkreślane są głównie te przejawy zachowań między osobnikami jednego gatunku, jak i pomiędzy gatunkami, które określić można jako pozytywne ze specyficznie ludzkiej perspektywy moralnej. Projekcja ta pełni funkcje specyficznie społeczne. Wszak nawet nie akceptując tego rodzaju konstruktywizmu i uznając inne gatunki takimi, jakimi są w swoim niedostępnym nam samorozumieniu, docieramy do uniwersalnej zdolności odczuwania cierpienia oraz roli empatii w kształtowaniu się ocen moralnych.

Topos cierpienia w analizowanym materiale był wykorzystywany jako nadrzędny argument na rzecz praw zwierząt, a sama negatywna ocena cierpienia nie podlegała dalszym uzasadnieniom, jak w myśli Richarda Rorty'ego (1996). Istnieją więc filozoficzne podstawy do budowania analogii między cierpieniem ludzi i zwierząt, zatarte jednak przez dyskurs „karnizmu” (Joy 2017). To na jego przełamywaniu skupia się właśnie analizowana kampania.

Waga przykładana w dyskursie publicznym do cierpienia zwierząt wiąże się prawdopodobnie z szerszą tendencją malejącej tolerancji współczesnych społeczeństw zachodnich wobec przemocy skierowanej przeciwko ludziom. Jak uważał Janusz Tazbir (1993), zadawanie bólu czy cierpień zwierzętom zaczyna być potępiane mniej więcej $\mathrm{w}$ tym samym okresie, gdy pojawia się sprzeciw wobec kar fizycznych czy tortur $\mathrm{w}$ postępowaniach sądowych. W tym samym okresie pojawiają się również, choć bardzo stopniowo, krytyczne komentarze dotyczące królewskich polowań, a szczucie zwierząt na siebie nawzajem zaczyna być odbierane jako coś okrutnego (Tazbir 1993). 
Wątki związane z ukazywaniem człowieka jako istoty $\mathrm{z}$ natury niezdolnej do samodzielnego zabicia zwierzęcia stanowią jeszcze jedną istotną tendencję w argumentacji rzeczników praw zwierząt. Intensyfikacja produkcji zwierzęcej oraz jej ukrywanie w przestrzeniach zamkniętych i niewidocznych dla mieszkańców miast spowodowały, że zabijanie zwierząt stało się wręcz „niewidzialne" (Cook 2015). Mamy do czynienia z wyraźnym oddzieleniem konsumenta od procesu produkcji mięsa, a jednocześnie powszechne jest traktowanie zwierząt towarzyszących jak członków rodziny (Konecki 2005). W zestawieniu z drastycznymi materiałami pokazującymi realia funkcjonowania przemysłowych tuczarni czy ubojni, stosunek do zwierząt domowych wywołuje wrażenie trudnego do zaakceptowania kontrastu (w rozumieniu Simmla 2006) i rodzi emocjonalny sprzeciw. Różnica $\mathrm{w}$ traktowaniu różnych gatunków jest skwapliwie wykorzystywana w budowaniu argumentacji przez aktywistów podkreślających niekonsekwencję w działaniu osób darzących jedne zwierzęta znacznymi względami, a ignorujących cierpienia i zabijanie innych.

Warto zwrócić uwagę na zidentyfikowaną w literaturze kluczową rolę emocji w kształtowaniu ocen moralnych i niebagatelną rolę materiałów audio-wizualnych. Choć w podstawowym korpusie biuletynu nie znalazły się żadne drastyczne obrazy pokazujące przemoc wobec zwierząt, dodatkowe źródła i materiały polecane przez organizatorów zawierały tego typu sceny. Jak już obszerniej wskazano w części teoretycznej, ekspozycja na ten rodzaj materiałów może intensywnie oddziaływać na emocje odbiorców i wywołać wstrząs moralny (Jasper, Poulsen 1995), który z kolei jest kluczowy dla „przewartościowania wartości” i zmiany stylu życia.
W celu zmiany zachowań uczestników programu "Zostań Wege na 30 dni", omawianego w niniejszym artykule, aktywiści odwołują się nie tylko do współczucia czy racjonalności, które zasygnalizowane zostały wyżej jako główne motywy historycznego rozwoju praw zwierząt, ale również w ogromnym stopniu do instynktownego wstrętu i poczucia zagrożenia, które mogą także sprzyjać powstawaniu społecznego tabu. Jak pisze Mary Douglas (2007), wierzenia związane z nieczystością mogą wspierać podtrzymywanie kodeksów moralnych. Stanowią one nawet rodzaj „,zdepersonalizowanej kary" za wykroczenie, zapewniając środki do podtrzymywania ustanowionego i akceptowanego systemu moralnego (Douglas 2007). W omawianym kontekście dzieje się to na kilku poziomach. Po pierwsze, aktywiści w drastyczny sposób opisują realia życia zwierząt hodowlanych, wzmacniając wrażenie bezpośrednich konsekwencji spożywania nawet najmniejszych ilości produktów odzwierzęcych. Drugim poziomem jest definiowanie mięsa jako ciała żywej istoty, a nie produktu do jedzenia. Taka redefinicja prowadzić może do tego, że eliminacja mięsa z diety skutkuje duchowym odrodzeniem, ukazywanym nie tylko jako poprawa jakości życia, lecz także jako osiągnięcie harmonii ze światem i szczęście. Te konsekwencje reinterpretacji cielesności zwierzęcia stwarzają ciekawe perspektywy teoretyczne, ponieważ pozwalają zapytać o konsekwencje przeniesienia ciała zwierząt w obszar sfery sacrum i możliwe skutki tego przeniesienia dla praktyk i struktur społecznych. Chociaż rozważania te są tu tylko hipotetyczne, to warto zwrócić uwagę, że w literaturze socjologicznej pojawiają się już analizy pozwalające kreślić podobne paralele - choćby studia nad pochówkiem zwierząt towarzyszących, podobnym do pogrzebów ludzkich (Pręgowski 2014). Świadomość, że są to "tylko zwierzęta” ustępuje miejsca celebrowaniu własnej pamięci, ale tak- 
że czci wobec ciała zwierzęcia i odczuciom metafizycznym o proweniencji religijnej. Prześledzenie tej ewolucji w biografii ludzi korzystających z cmentarzy dla zwierząt i społeczności związanych z tego rodzaju usługami z pewnością zasługuje na odrębne badania etnograficzne.

Przyglądając się szerszym tendencjom, w które wpisuje się szereg niekiedy ciągle jeszcze marginalnych zjawisk, warto zwrócić uwagę na dwie, które wyróżnił Janusz Tazbir (1993). Charakteryzując ogólnie historię stosunku człowieka do zwierząt, podzielił ją w pewnym uproszczeniu na dwa okresy. Pierwszy obejmuje skupianie się na zagrożeniach, jakie niesie natura wraz z należącymi do niej istotami. W tym okresie dominują narracje o zagrożeniach czyhających na ludzi w czasie wypraw morskich czy w ciemnej puszczy. Obowiązywała zasada „ujarzmić i wykorzystać, a w razie oporu, zniszczyć" (Tazbir 1993: 149-150). Drugi okres, rozpoczynający się pod koniec czasów nowożytnych, charakteryzował się natomiast stopniowym uwzględnianiem tego, jakie niebezpieczeństwa niesie ze sobą działalność człowieka (Tazbir 1993).

\section{Bibliografia}

Alexander Jeffrey C. (1988) Introduction: Durkheimian Sociology and Cultural Studies Today [w:] idem, ed., Durkheimian Sociology: Cultural Studies. Cambridge: Cambridge University Press, s. 1-21.

Alexander Jeffrey C. (2006) The Civil Sphere. New York: Oxford University Press.

Barcz Anna, Dąbrowska Magdalena (2014) Wstęp [w:] Anna Barcz, Magdalena Dąbrowska, red., Zwierzęta, gender i kultura. Perspektywa ekologiczna, etyczna i krytyczna. Lublin: E-naukowiec, s. 7-15.
Także współczesna socjologia, rozumiejąc społeczeństwo jako system, zwraca uwagę na jego rosnącą wrażliwość na konieczność dostosowania się do własnego otoczenia i idącą za tym przemianę własnych struktur (Luhmann 2012). Przemiany te sa przedmiotem badań ekonomiczno-ekologicznych, ale jednym $\mathrm{z}$ ich nieodzownych elementów jest także ewolucja społecznej samoświadomości, której owocem są ruchy ekologiczne. Ruchy prozwierzęce odgrywają w tej ewolucji rolę szczególną i niejednoznaczną. Z jednej strony wskazują na rosnącą wrażliwość całego społeczeństwa na środowisko przyrodnicze, ale z drugiej strony zdają się rozszerzać granice wspólnoty tak, by objęła także zwierzęta, a być może również wszystkie żywe istoty, podważając tym samym samą koncepcje granicy między społeczeństwem ludzkim a jego ekosystemem. Ponadto z jednej strony wskazują na rosnący indywidualizm, którego przejawem jest empatia wobec zindywidualizowanych istot żywych, ale z drugiej strony są być może zwiastunem nowego kolektywizmu, obejmującego nie tylko ludzi, lecz wszystkie istoty żywe, oraz solidarności uświęcającej życie we wszelkich jego postaciach.

Berger Peter L., Luckmann Thomas (2010) Społeczne tworzenie rzeczywistości. Traktat z socjologii wiedzy. Przełożył Józef Niżnik. Warszawa: Wydawnictwo Naukowe PWN.

Blumer Herbert (2007) Interakcjonizm symboliczny. Przełożyła Grażyna Woroniecka. Kraków: Nomos.

Burdziej Stanisław (2011) Niektóre problemy z tłumaczeniem Frame Analysis Ervinga Goffmana - perspektywa tłumacza. „Przegląd Socjologii Jakościowej", t. 7, nr 2, s. 42-53. 
Coleman James (1990) Foundations of Social Theory. Cambridge, MA: Belknap Press.

Cook Guy (2015) "A pig is a person" or "you can love a fox and hunt it": Innovation and tradition in the discursive representation of animals. „Discourse \& Society”, vol. 26, no. 5, s. 587-607.

Cukras-Stelągowska Joanna (2015) Wokół debaty nad ubojem rytualnym w Polsce - analiza dyskursów publicznych. „Społeczeństwo i Polityka", t. 4, nr 45, s. 139-156.

Douglas Mary (2007) Czystość i Zmaza. Przełożyła Marta Bucholc. Warszawa: Państwowy Instytut Wydawniczy.

Fairclough Norman (1992) Discourse and Social Change. Cambridge: Polity Press.

Francuz Grzegorz (2011) Strategie przypisywania statusu moralnego istotom żywym. Opole: Wydawnictwo Uniwersytetu Opolskiego.

Freeman Carrie P. (2010) Framing Animal Rights in the "Go Veg" Campaigns of U.S. Animal Rights Organizations. "Society and Animals", no. 18, s. 163-182.

Freeman Carrie.P (2013) Stepping Up to the Veggie Plate: Framing Veganism as Living Your Values [w:] Emily Plec, ed., Perspectives on Human Animal Communication: Intercultural Communication. New York: Routledge, s. 93-112.

Goffman Erving (1981) Człowiek w teatrze życia codziennego. Przełożyli Helena Datner-Śpiewak, Paweł Śpiewak. Warszawa: PIW.

Gzyra Dariusz (2017) Problemy ekstensjonizmu etycznego [w:] Beata A. Nowak, Kamil Maciąg, red., Filozoficzne rozważania o naturze człowieka, Lublin: Wydawnictwo Naukowe TYGIEL, s. 135-149.

Habermas Jurgen (2005) Faktyczność i obowiązywanie: teoria dyskursu wobec zagadnień prawa i demokratycznego państwa prawnego. Przełożyli Adam Romaniuk, Robert Marszałek. Warszawa: Wydawnictwo Naukowe Scholar.

Haidt Jonathan (2001) The Emotional Dog and Its Rational Tail: A Social Intuitionist Approach to Moral Judgment. „Psychological Review", vol. 108 , no. 4, s. 814-834.

Herzog Harold A., Golden Lauren L. (2009) Moral Emotions and Social Activism: The Case of Animal Rights. "Journal of Social Issues", vol. 65, no. 3, s. 485-498.
Honneth Axel (2012) Walka o uznanie. Moralna gramatyka konfliktów społecznych. Przełożył Jakub Duraj. Kraków: Zakład Wydawniczy Nomos.

Jacobsson Kerstin, Lindblom Jonas (2013) Emotion work in animal rights activism: A moral-sociological perspective. "Acta Sociologica", vol. 56, no. 1, s. 55-68.

Jasper James M., Poulsen Jane D. (1995) Recruiting Strangers and Friends: Moral Shocks and Social Networks in Animal Rights and Anti-Nuclear Protests. „,Social Problems”, vol. 42, no. 4, s. 493-512.

Joas Hans (2010) Powstawanie wartości. Przełożył Michał Kaczmarczyk. Warszawa: Oficyna Naukowa.

Joy Melanie (2017) Beyond Beliefs: A Guide to Improving Relationships and Communication for Vegans, Vegetarians, and Meat Eaters. Petaluma, CA: Roundtree Press.

Kaczmarczyk Michał (2019) An Invasion of Tricksters: Critical Remarks on Bruno Latour's Social Theory and Its Polish Reception. „Studia Socjologiczne", t. 235, nr 4, s. 5-44.

Konecki Krzysztof T. (2005) Ludzie i ich zwierzęta. Interakcjonistyczno-symboliczna analiza społecznego świata właścicieli zwierzat domowych. Warszawa: Scholar.

Luhmann Niklas (2012) Systemy społeczne. Zarys ogólnej teorii. Przełożył Michał Kaczmarczyk. Kraków: Zakład Wydawniczy Nomos.

Mamzer Hanna (2014) Zwierze jako podmiot. O metastrategiach kolonizowania przyrody. „Porównania”, nr 15, s. 75-90.

McDonald Barbara (2000) “Once you know something, you can't not know it": An empirical look at becoming vegan. „Society \& Animals", vol. 8, no. 1, s. 1-23.

Nowosielski Michał (2011) Socjologiczna refleksja na temat ruchów społecznych. „Przegląd Zachodni”, nr 4, s. 3-28.

Parsons Talcott (2009) System społeczny. Przełożył Michał Kaczmarczyk. Kraków: Zakład Wydawniczy Nomos.

Peters Anne (2020) Introduction [w:] Anne Peters, ed., Studies in Global Animal Law. Heidelberg: Max Planck Institute for Comparative Public Law and International Law, s. 1-13.

Pisarek Walery (2000) Polskie słowa sztandarowe i ich publiczność: lata dziewięćdziesiate. "Zeszyty prasoznawcze”, t. 43, nr 3-4, s. 19-41. 
Pręgowski Michał P. (2014) "Najwierniejszy, najukochańszy". Ostatnie pożegnania opiekunów z psami [w:] Michał P. Pręgowski, Justyna Włodarczyk, red., Pies też człowiek? Relacje psów i ludzi we wspótczesnej Polsce. Gdańsk: Wydawnictwo Naukowe Katedra, s. 157-178.

Rancew-Sikora Dorota (2009) Sens polowania. Wspótczesne znaczenia tradycyjnych praktyk na przykładzie dyskursu łowieckiego. Warszawa: Scholar.

Rancew-Sikora Dorota (2010) Procedury zaznaczania i przekraczania granic gatunku ludzkiego w opowieściach miłośników zwierząt [w:] Krzysztof T. Konecki, Anna Kacperczyk, red., Procesy tożsamościowe. Symboliczno-interakcyjny wymiar konstruowania ładu i nieładu społecznego. Łódź: Wydawnictwo Uniwersytetu Łódzkiego, s. 113-138.

Rorty Richard (1996) Przygodność, ironia i solidarność. Przełożył Jan Popowski. Warszawa: Wydawnictwo Spacja.

Rozin Paul, Haidt Jonathan, McCauley Clark R. (2008) Disgust [w:] Michael Lewis, Jeannette M. Haviland-Jones, Lisa F. Barrett, eds., Handbook of Emotions, third edition. New York: Guilford Press, s. 757-776.
Ryan Charlotte, Gamson William A. (2006) The Art of Reframing Political Debates. „Contexts”, vol. 5, no. 1, s. 13-18.

Searle John (1999) Umyst, język, społeczeństwo. Filozofia i rzeczywistość. Przełożyła Dominika Cieśla. Warszawa: Wydawnictwo Cis.

Simmel Georg (2006) Most i drzwi. Wybór esejów. Przełożyła Małgorzata Łukasiewicz. Warszawa: Oficyna Naukowa.

Snow David A., Benford Robert D. (1988) Ideology, Frame Resonance and Participant Mobilization [w:] Bert Klandermans, Hanspeter Kriesi, Sidney G. Tarrow, eds., From structure to action: Comparing social movement research across cultures. Greenwich: JAI Press, s. 197-218.

Sztompka Piotr (2012) Socjologia. Analiza społeczeństwa. Kraków: Wydawnictwo Znak.

Tazbir Janusz (1993) Okrucieństwo w nowożytnej Europie. Warszawa: Polska Oficyna Wydawnicza „BGW”.

van Dijk Teun A. (2001) Badania nad dyskursem [w:] Teun A. van Dijk, red., Dyskurs jako struktura i proces. Warszawa: Wydawnictwo Naukowe PWN.

\title{
Cytowanie
}

Jaczewska Joanna (2021) Społeczna konstrukcja praw zwierzat na przykładzie kampanii "Zostań Wege na 30 dni". „Przegląd Socjologii Jakościowej", t. 17, nr 2, s. 84-108 [dostęp dzień, miesiąc, rok]. Dostępny w Internecie: ‘www.przegladsocjologiijakosciowej.org〉. DOI: https://doi.org/10.18778/1733-8069.17.2.05

\section{The Social Construction of Animal Rights Based on the Example of the 'Become Vegan/ Vegetarian for 30 Days' Campaign}

\begin{abstract}
Classical explanations of the genesis of social values and norms refer to mechanisms that more or less directly facilitate the development of human societies. However, the explanation of moral norms pertaining to other species remains a riddle. The main theoretical idea of the article is to extend the catalog of ways in which norms emerge (according to Hans Joas' classification). The article investigates the strategies of animal rights construction within pro-animal discourse using the techniques of structure and content analysis. The analyzed material was derived from the 'Become Vegan/Vegetarian for 30 Days' social campaign, whose main goal has been to motivate people to give a plant-based diet a try. Based on the analysis, four main strategies of attitude-change towards non-human species have been identified: a) the redefinition of animal status; b) the redefinition of human action; c) the redefinition of eating animals; and d) the signaling of positive consequences of animal rights implementation.
\end{abstract}

Keywords: animal studies, animal rights, values, social movements, discourse analysis 